\title{
Platelet-derived Growth Factor Promotes Proliferation of Erythropoietic Progenitor Cells In Vitro
}

\author{
Nicholas Dainiak, Gregg Davies, Maria Kalmanti, Jack Lawler, and \\ Vivekanand Kulkarni, Departments of Medicine and Biomedical Research, \\ Division of Hematology/Oncology, St. Elizabeth's Hospital of Boston, \\ Department of Medicine, Tufts University School of Medicine, Boston, \\ Massachusetts 02135
}

\begin{abstract}
A в S T R A C T To investigate serum requirements for optimal erythropoiesis in vitro, we studied the response of erythroid progenitor cell proliferation in culture to platelet-derived growth factor (PDGF). Human bone marrow cells cultured with platelet-poor plasma-derived serum (PDS) form fewer erythroid colonies than do cells cultured with human whole blood serum or fetal calf serum $(P<0.05)$. Treatment of washed platelets with thrombin releases a low molecular weight $(<100,000)$ factor that enhances colony growth. This secreted factor appears to be PDGF, based upon the ability of partially purified and electrophoretically pure PDGF to restore colony-forming capacity of PDScontaining cultures to $70-96 \%$ of the level found in control cultures with whole blood serum or fetal calf serum. Enhancement of colony growth by PDGF was noted only in marrow cultures supplemented with erythropoietin and PDS. Presence of bioactive erythropoietin in PDGF preparations was excluded by assay in hypertransfused, polycythemic mice, and in fasted rats. Although PDGF stimulates erythroid burst formation in marrow cultures containing optimal concentrations of burst-promoting activity (BPA), it does not influence proliferation of circulating erythroid bursts, regardless of BPA concentration added to culture. We conclude that PDGF is a serum determinant of optimal erythroid progenitor cell proliferation in marrow culture. The activity of PDGF is distinct from that of the apparent erythroid specific growth factors erythropoietin and BPA.
\end{abstract}

A preliminary report of this research was presented at the 23rd Annual Meeting of the American Society of Hematology, San Antonio, TX, and published in abstract form in 1981. Blood. 58: 95a.

Address reprint requests to Dr. Dainiak, Department of Research, St. Elizabeth's Hospital, 736 Cambridge Street.

Received for publication 7 June 1982 and in revised form 10 January 1983.

\section{INTRODUCTION}

Erythroid progenitors known as colony-forming unitserythroid (CFU-E) ${ }^{1}$ and burst-forming units-erythroid (BFU-E, or bursts) can be assayed by their in vitro capacity to proliferate in response to tissue-specific regulators such as erythropoietin and burst-promoting activity (1). It is believed that mammalian serum provides an appropriate balance of nutritional factors essential for optimal colony formation (1-3). For example, albumin, transferrin, iron, and a variety of lipids must be present at critical concentrations for CFU-E proliferation to occur in serum-free cultures $(4,5)$. In addition, serum may contain peptide hormones or hormonelike growth factors that are required for optimal erythroid cell proliferation (6-8).

Recently, platelet-derived growth factor (PDGF), a low molecular weight platelet secretory protein, has been shown to stimulate the division of several different types of mammalian cells in culture (9-11). To determine whether PDGF may be an important serum factor for proliferation of erythropoietic progenitor cells, we have measured the effect of secreted platelet products and of purified PDGF on the proliferation of CFU-E and BFU-E derived from human bone marrow. We have found that colony growth is significantly enhanced by whole blood serum (WBS) in comparison to platelet-poor plasma-derived serum (PDS). The stimulatory factor is a heat-stable, low molecular weight material released by thrombin treatment of washed platelets. Since partially purified and electrophoretically pure PDGF significantly enhance ery-

\footnotetext{
${ }^{\prime}$ Abbreviations used in this paper: ACD, acid citrate dextrose; BFU-E, burst-forming unit, erythroid; BPA, burst-promoting activity; CFU-E, colony-forming unit, erythroid; CM, conditioned media; FCS, fetal calf serum; PDGF, platelet-derived growth factor; PDS, platelet-poor plasma-derived serum.
} 
throid colony formation, we suggest that PDGF is a serum determinant of optimal CFU-E and BFU-E proliferation by bone marrow cells in vitro.

\section{METHODS}

Preparation of WBS and PDS. WBS and PDS were prepared by the method of Vogel et al. $(12,13)$. Briefly, fresh blood was obtained from normal AB-positive volunteers with informed consent and approval of an Institutional Review Board. Blood was mixed in plastic tubes with one-ninth volume of $3.8 \%$ sodium citrate and divided into two equal portions. One portion of blood was clotted by addition of oneseventieth volume of $1 \mathrm{M} \mathrm{CaCl}_{2}$, followed by incubation for $2 \mathrm{~h}$ at $37^{\circ} \mathrm{C}$ and centrifugation at $1,100 \mathrm{~g}$ for $15 \mathrm{~min}$ at $4^{\circ} \mathrm{C}$. The resulting WBS was recentrifuged at $31,000 \mathrm{~g}$ for $30 \mathrm{~min}$ to remove any residual platelets and then was dialyzed for 1-2 d against large volumes of $140 \mathrm{mM} \mathrm{NaCl}, 10 \mathrm{mM}$ sodium phosphate, pH 7.4 (phosphate-buffered saline, PBS). In some experiments, the WBS was concentrated severalfold after dialysis by use of Sephadex G-200 around the dialysis bag. After heating at $56^{\circ} \mathrm{C}$ for $30 \mathrm{~min}$, the dialyzed solution was centrifuged at $31,000 \mathrm{~g}$ for $30 \mathrm{~min}$ at $4^{\circ} \mathrm{C}$. The supernatant solution was sterilized by passage through a $0.45-\mu \mathrm{m}$ Millipore filter (Millipore Corp., Bedford, MA) and stored at $4^{\circ}$ or $-20^{\circ} \mathrm{C}$ until use. For preparation of PDS, the second portion of citrate-anticoagulated blood was centrifuged at 1,100 $g$ for $20 \mathrm{~min}$ at $4^{\circ} \mathrm{C}$. The plasma was recentrifuged at 31,000 $g$ for $20 \mathrm{~min}$ and then clotted by addition of one-fiftieth volume of $1 \mathrm{M} \mathrm{CaCl}_{2}$. Subsequent processing was identical to that described for preparation of WBS.

Isolation of platelet secretory products. Platelet concentrates from one or two pheresis donors $(8-21 \mathrm{U})$ were obtained from the American Red Cross Blood Services, Boston, MA within $36 \mathrm{~h}$ of donation. A one-fourth volume of anticoagulant acid citrate dextrose (ACD National Institutes of Health formula $A$ ) was added, and the platelets were pelleted by centrifugation at $900 \mathrm{~g}$ for $15 \mathrm{~min}$. The platelets were resuspended in $0.02 \mathrm{M}$ Tris- $\mathrm{HCl}(\mathrm{pH} 7.6), 0.15 \mathrm{M} \mathrm{NaCl}$, $5 \mathrm{mM}$ glucose and $10 \%$ ACD; centrifuged at $200 \mathrm{~g}$ for $6 \mathrm{~min}$ to remove contaminating erythrocytes and leukocytes; and then washed three times in the same buffer. The platelets were then resuspended in Tris-buffered saline without ACD $(4 \mathrm{ml} / \mathrm{U})$ and the $\mathrm{pH}$ was readjusted to $\mathrm{pH} 7.6$, if necessary, prior to the addition of $1 \mathrm{U} / \mathrm{ml}$ of purified human thrombin (provided by Dr. J. Fenton II) to the stirred platelet suspension at $37^{\circ} \mathrm{C}$. After $2 \mathrm{~min}, 2 \mathrm{U}$ of hirudin (Pentapharm, Switzerland) $/ \mathrm{ml}$ of platelet suspension was added, and the aggregates were allowed to settle. EDTA was added to bring the supernatant to $1 \mathrm{mM}$. After decantation and centrifugation at $20,000 \mathrm{~g}$ for $20 \mathrm{~min}$, the sample was applied to a column $(5 \times 90 \mathrm{~cm})$ of Sepharose $4 \mathrm{~B}$ equilibrated with 0.02 $\mathrm{M}$ Tris- $\mathrm{HCl}\left(\mathrm{pH} \mathrm{7.6),} 0.15 \mathrm{M} \mathrm{NaCl}\right.$ and $1 \mathrm{mM}$ EDTA at $4^{\circ} \mathrm{C}$. The column fractions were analyzed for total protein by the method of Lowry et al. (14), using bovine serum albumin (BSA) as the standard, and for platelet factor 4 and $\beta$-thromboglobulin-related antigen by radioimmunoassay kits prepared by Abbott Laboratories, North Chicago, IL and Amersham Corp., Arlington Heights, IL, respectively. Thrombospondin was purified from the supernatant of a thrombin-treated platelet suspension by heparin-Sepharose affinity chromatography in the presence of $1 \mathrm{mM}$ EDTA, as described previously (15).

Preparation of crude platelet extracts by heat treatment or sonication. Heat-treated platelet extracts were prepared by a modification of the method of Antoniades et al. (10).
Platelets from concentrates were washed twice with a solution containing $9 \mathrm{vol}$ of $150 \mathrm{mM} \mathrm{NaCl}, 17 \mathrm{mM}$ Tris hy-

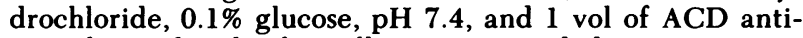
coagulant. The platelet pellet was suspended in a minimum volume of buffer containing $80 \mathrm{mM} \mathrm{NaCl}, 10 \mathrm{mM}$ Na phosphate, pH 7.4. After freezing and thawing, additional buffer was added to produce a volume of $4 \mathrm{ml}$ for each unit of platelets processed. The sample was heated for $10 \mathrm{~min}$ in a boiling water bath and centrifuged for $20 \mathrm{~min}$ at $10,000 \mathrm{~g}$. The supernatant was retained, and the pellet was extracted twice by stirring for several hours with $2 \mathrm{ml}$ of $1 \mathrm{M} \mathrm{NaCl}$ for each unit of platelets. All supernatants were combined, concentrated, dialyzed, centrifuged, and sterilized as described for preparation of WBS and PDS. Sonicated platelet extracts were prepared by substitution of sonication (1 min at $4^{\circ} \mathrm{C}$, using a Heat Systems-Ultrasonics model W-185 at a setting of 4) for the heat step.

Assays for erythropoietic growth promoting activity. Bone marrow cells were aspirated from the posterior iliac crests of 26 hematologically normal donors and placed in Eagle's minimum essential media (MEM) containing $20 \mathrm{U} /$ $\mathrm{ml}$ preservative-free heparin (Gibco Laboratories, Grand Island Biological Co., Grand Island, NY). $50 \mathrm{ml}$ of venous blood was withdrawn from the antecubital veins of three healthy donors and placed in an equal volume of RPMI-1640 (Gibco Laboratories) containing $20 \mathrm{U} / \mathrm{ml}$ heparin. Informed consent was obtained prior to aspiration, in accordance with an Institutional Review Board. The mononuclear cells appearing at the interface after centrifugation over FicollPaque (Pharmacia Fine Chemicals, Piscataway, NJ) were separated, washed three times in $\alpha$-medium (Flow Laboratories, Inglewood, $\mathrm{CA}$ ), and cultured at $d 6 \times 10^{5}$ marrow cells $/ \mathrm{ml}$ and $1 \times 10^{6}$ peripheral blood cells $/ \mathrm{ml}$ in fibrin clots according to the method of Tepperman et al. (16) with the following modifications. The culture mixture was prepared with FCS, WBS, or PDS at final concentrations of $0,9,18$, or $27 \%$ ( $\mathrm{vol} / \mathrm{vol})$. Since many platelet secretory products contain disulfide bonds that may be sensitive to the reducing actions of thiol-containing components, $\alpha$-thioglycerol was routinely omitted from culture, unless otherwise specified. Clots were formed in microtiter wells with $0.1 \mathrm{mg} / \mathrm{ml} \mathrm{highly}$ purified human fibrinogen (Kabi AG, Stockholm, Sweden), $2 \mathrm{mM} \mathrm{CaCl}_{2}$ and $5 \mathrm{U} / \mathrm{ml}$ thrombin. Cultures were established in the presence of $0.0,0.1,0.5,1,2$, or 4 International Units (IU)/ml of sheep step III erythropoietin (Connaught Laboratories, Willowdale, Ontario, Canada).

After incubation at $37^{\circ} \mathrm{C}$ in humidified air containing $4 \%$ $\mathrm{CO}_{2}$, the clots were removed, fixed on glass slides in glutaraldehyde and stained with benzidine and hematoxylin. CFU-E-derived colonies appeared as clusters of greater than or equal to eight benzidine-positive cells in marrow cultures after 6 or $7 \mathrm{~d}$ of incubation, and BFU-E-derived colonies appeared as single aggregates $\geq 50$ benzidine-positive cells or as $\geq 3$ aggregates of $8-49$ benzidine-positive cells in marrow and peripheral blood cultures after 12-14 d of incubation. Colonies were enumerated under 100 times magnification. In cultures with $27 \%$ FCS, mean CFU-E- and BFUE-derived colony formation by $6 \times 10^{5}$ marrow mononuclear cells ranged from 14 to 63 and from 12 to 31 colonies, respectively. Mean burst formation by $1 \times 10^{6}$ peripheral blood mononuclear cells ranged from 8 to 20 colonies. The ability of WBS, PDS, and/or PDGF to support colony formation was calculated as the percent maximum colonies, with maximum growth occurring in cultures containing 27\% FCS in our laboratory.

Column fractions of supernatants from thrombin-treated platelets were assayed for colony stimulatory activity in cul- 
tures prepared with PDS. $100 \mu \mathrm{l}(9.0 \%$, vol/vol) of material from each fraction were added at a final protein concentration of $2.5 \mu \mathrm{g} / \mathrm{ml}$, and growth was compared to that in cultures containing $100 \mu \mathrm{l}$ of NCTC-109 (Microbiological Associates, Bethesda, MD). Partially purified PDGF (specific activity of $66.7 \mathrm{U} / \mathrm{mg}$ of protein) obtained from Collaborative Research (Waltham, MA) was dissolved in distilled water according to the manufacturer's directions for use and diluted in NCTC-109 to achieve the final protein concentrations denoted in the figure legends. $100 \mu \mathrm{l}$ were added to cultures prepared with PDS and to serum-free cultures that were supplemented with $340 \mu \mathrm{g} / \mathrm{ml}$ transferrin, 1.6 $\times 10^{-6} \mathrm{M}$ ferric chloride and $10^{-7} \mathrm{M}$ sodium selenite, as described by Iscove et al. (5). Samples of electrophoretically pure PDGF were kind gifts of Dr. Elaine W. Raines and Dr. Russel Ross (17) and of Dr. Charles D. Stiles (18). The former sample was dissolved in $1 \mathrm{mM}$ acetic acid and diluted in PBS plus bovine serum albumin (BSA) at a final BSA concentration of $2 \mathrm{mg} / \mathrm{ml}$. The latter sample containing $0.1 \mathrm{mg} / \mathrm{ml}$ BSA was diluted in NCTC-109. $100 \mu \mathrm{l}$ of purified PDGF were added to culture to produce final concentrations of $10^{-5}$ to $1 \mathrm{ng} / \mathrm{ml}$. Concurrently run controls for each marrow culture contained $100 \mu \mathrm{l}$ of NCTC-109. Stimulation was calculated as percentage of growth in cultures to which NCTC109 alone was added to the culture mixture.

Preparation and assay of conditioned media (CM). Serum-free conditioned medium was prepared with $150 \mathrm{ml}$ of peripheral blood from a healthy donor that was collected into $\alpha$-medium containing $20 \mathrm{U} / \mathrm{ml}$ heparin. Mononuclear cells separated over Ficoll-Paque were mixed for $20 \mathrm{~min}$ with a carbonyl iron suspension (Technicon Instruments Corp., Tarrytown, NY) and separated again over FicollPaque to deplete them of macrophages. Greater than $98 \%$ of the interface cells were nonspecific esterase negative. They were washed three times in $\alpha$-medium and resuspended at a $d 5 \times 10^{6} / \mathrm{ml}$ in tissue culture flasks in $\alpha$-medium with L-glutamine, streptomycin, and penicillin (Gibco Laboratories). CM was harvested after $24 \mathrm{~h}$ of incubation at $37^{\circ} \mathrm{C}, 4 \% \mathrm{CO}_{2}$ and freed of cells by centrifugation at 280 $g$ for $20 \mathrm{~min}$. Greater than $98 \%$ of the cells excluded trypan blue. Control medium was incubated in the absence of cells. Burst-promoting activity (BPA) present in CM was assayed as previously described (19) in marrow or peripheral blood cultures containing 4.5\% PDS. CM was added at final concentrations of $0.0,0.9,4.5,9.0,13.5,18.0$, or $27.0 \%(\mathrm{vol} / \mathrm{vol})$ in the presence and absence of $0.01 \mathrm{ng} / \mathrm{ml}$ purified PDGF. Colony growth was compared to that observed in cultures concurrently established with $27 \%$ FCS and no added CM or PDGF

Statistical analysis. The mean \pm 1 SEM colonies formed in quadruplicate cultures was determined and data sets were compared by the two sample ranks test of Wilcoxon-White (20), unless otherwise stated.

Assays for in vivo erythropoietin activity. Since it is possible that platelet secretory products have erythropoietic stimulatory activity similar to that of erythropoietin, we assayed PDS, WBS, and a partially purified PDGF for in vivo erythropoietin bioactivity in plethoric animals using two assay systems. In the first, $0.5 \mathrm{ml}$ of test material, isotonic saline or sheep step III erythropoietin standards were injected subcutaneously on two consecutive days into each of five hypertransfused, polycythemic $\mathrm{CF}_{1}$ mice (Cartworth Laboratories, Woburn, MA). Mice with hematocrits < 55\% were excluded from the assay. $24 \mathrm{~h}$ later, ${ }^{59} \mathrm{Fe}$ was injected intravenously, and radioactive iron incorporated into circulating erythrocytes after $24 \mathrm{~h}$ was determined, according to the method of Shadduck, Howard, and Stohlman (21).
The erythropoietin activity in each sample was then determined by comparing radioactivity in samples from test animals with that from animals injected with standard materials (mean percent ${ }^{59} \mathrm{Fe}$ incorporations of $0.01,0.63,1.78$, and 2.95 for normal saline and $0.25,0.50$, and $1.00 \mathrm{IU} / \mathrm{ml}$ erythropoietin, respectively). In our laboratory, $<0.025 \mathrm{IU} /$ $\mathrm{ml}$ is detected in normal human serum. In the second assay system, rats were fasted for $60 \mathrm{~h}$ and then injected with 0.5 $\mathrm{ml}$ test or standard material as above. Those with hematocrits $<40 \%$ were excluded from the assay. ${ }^{59} \mathrm{Fe}$ was injected as above and radioactive iron incorporation was determined (21). Mean percent ${ }^{59} \mathrm{Fe}$ incorporations of $1.88,5.97,17.69$, and 19.19 were determined in samples from rats injected with normal saline or with $0.50,1.00$, or $1.50 \mathrm{IU} / \mathrm{ml}$ erythropoietin, respectively. In our hands, activity of $>0.5 \mathrm{IU} /$ ml may be detected by this method.

\section{RESULTS}

Support of colony growth by WBS or PDS. As shown in Fig. 1, relative to colony formation in WBS containing cultures, colonies were reduced at all PDS concentrations tested $(P<0.05)$. CFU-E and BFU-E proliferations in cultures containing 27\% PDS were only 28 and $15 \%$, respectively, of growth in conventional cultures containing $27 \%$ FCS $(P<0.01)$. In contrast, erythroid colony growth in cultures containing 27\% WBS was similar to growth in cultures containing

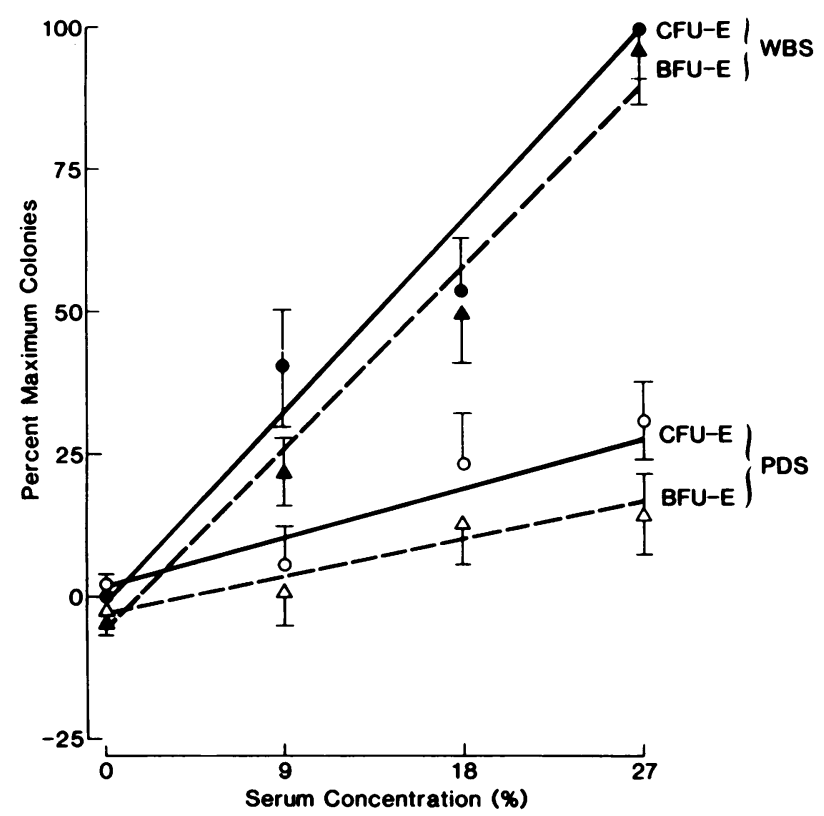

Figure 1 Colony formation as a function of final serum concentration. The graph shows mean $\pm \mathrm{SE}$ percent colonies in quadruplicate fibrin clot cultures with WBS (closed symbols) or PDS (open symbols). All cultures contained $2 \mathrm{IU} / \mathrm{ml}$ erythropoietin. Cultures with $100 \%$ maximum proliferation contained $23 \mathrm{CFU}$-E-derived and $14 \mathrm{BFU}-\mathrm{E}$-derived colonies $/ 6 \times 10^{5}$ marrow cells. Similar results were obtained in eight additional studies. Circles: CFU-E-derived colonies; triangles: BFU-E-derived colonies. 


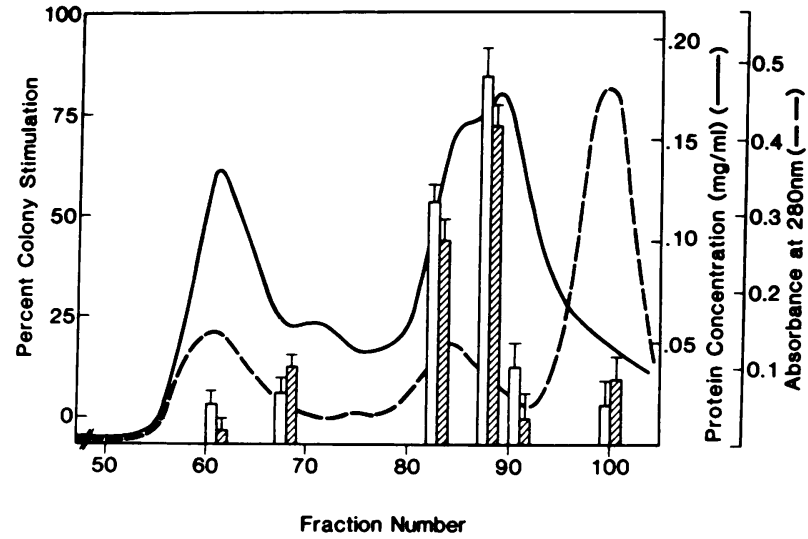

Figure 2 Colony stimulation by fractions of supernatant from thrombin-treated platelets. Mean $\pm S E$ percent stimulation of CFU-E derived (open bars) and BFU-E derived (cross-hatched bars) colonies in quadruplicate cultures is displayed for fractions obtained by gel filtration on Sepharose 4B. Cultures with $100 \%$ maximum proliferation contained $30 \mathrm{CFU}-\mathrm{E}$-derived and $12 \mathrm{BFU}-\mathrm{E}$-derived colonies/ $6 \times 10^{5}$ marrow cells. The final protein concentration was adjusted to $2.5 \mu \mathrm{g} / \mathrm{ml}$ for each fraction by dilution with PBS. Absorbance at $280 \mathrm{~nm}(---)$ and protein concentration by Lowry assay (-) are indicated. Fractions 80 and above contain proteins with molecular weights of $<100,000$. Cultures contained $2 \mathrm{IU} / \mathrm{ml}$ erythropoietin. Similar results were obtained in two additional studies.
$27 \%$ FCS $(P>0.10)$. This similarity was also evident in cultures containing lower WBS and FCS concentrations (data not shown). No colonies formed in the complete absence of serum or of added erythropoietin. The data indicate that platelets may be a source of an erythropoietic growth-promoting factor.

Colony stimulation by products released from treated platelets. To further test whether platelets can release colony growth promoting molecules, we treated a suspension of washed platelets with thrombin and assayed the supernatant for stimulatory activity in culture. Fig. 2 shows the elution profile of the crude supernatant on a Sepharose $4 \mathrm{~B}$ column. The maximum colony stimulating activity $(P<0.01)$ was eluted with a $K_{\mathrm{av}}$ of 0.72 (fractions 82-90). This peak in colony stimulatory activity corresponded to a protein peak that contains albumin, $\beta$-thromboglobulin-related antigen and PDGF (15). A second protein peak (fractions 58-68) that contains primarily thrombospondin and platelet factor 4-related antigen (presumably complexed to proteoglycan) did not stimulate colony growth. The peak in absorbance at $280 \mathrm{~nm}$ (fractions 95-105) was eluted at a bed volume and found to have an absorbance maximum at $255 \mathrm{~nm}$ indicating that this peak is comprised primarily of released adenine nucleotides. There was no significant colony stimulatory activity associated with this material (see Fig. 2).

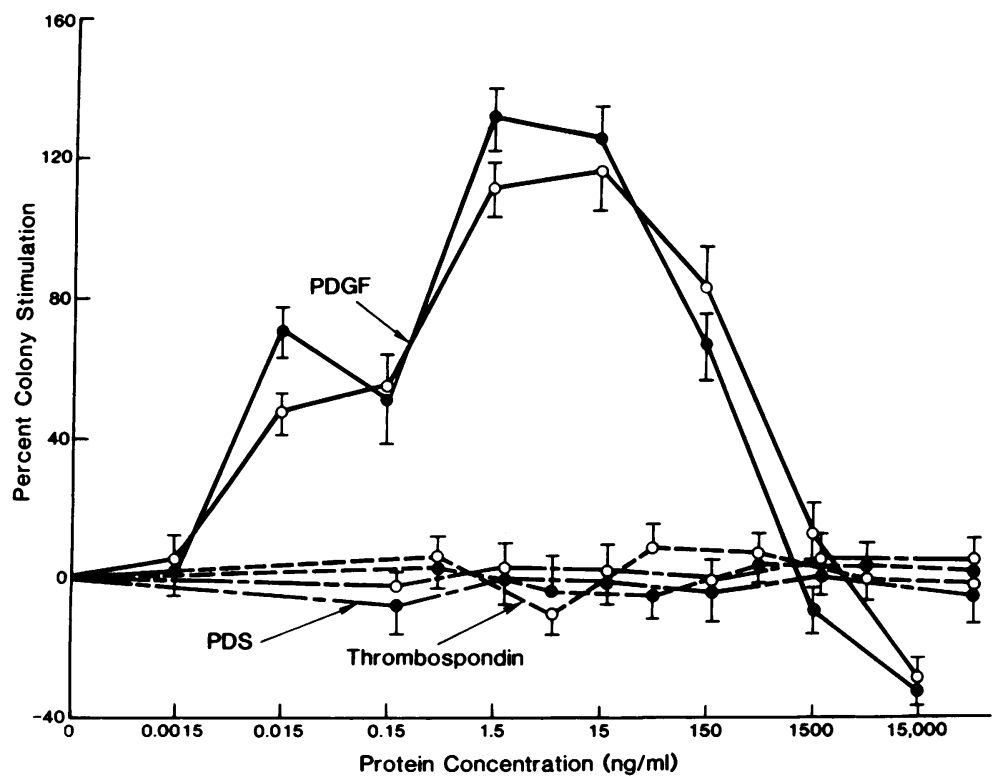

FIGURE 3 Effects of platelet secretory products on colony growth. Mean \pm SE percent stimulation of CFU-E-derived (closed circles) and BFU-E-derived (open circles) colonies is displayed for quadruplicate cultures containing $27 \%$ PDS, $2 \mathrm{IU} / \mathrm{ml}$ erythropoietin and $100 \mu \mathrm{l}(9 \%$, vol/ vol) test material. Maximum (100\%) CFU-E-derived and BFU-E-derived colony growth were 25 and $12 / 6 \times 10^{5}$ marrow cells, respectively. Similar results were obtained in one additional study. 
TABLE I

Stimulation of Colony Formation by Crude Platelet Extracts Prepared by Heating or Sonication

\begin{tabular}{lcc}
\hline & \multicolumn{2}{c}{ Percent colony stimulation } \\
\cline { 2 - 3 } \multicolumn{1}{c}{ Treatment } & Day 7 cultures & Day 13 cultures \\
\hline Heat $\left(100^{\circ} \mathrm{C}, 10 \mathrm{~min}\right)$ & $65 \pm 10$ & $89 \pm 7$ \\
Sonication $\left(4^{\circ} \mathrm{C}, 1 \mathrm{~min}\right)$ & $47 \pm 6$ & $48 \pm 11$ \\
\hline
\end{tabular}

All platelet suspensions were washed and alternately frozen and thawed prior to heating or sonication, as described in methods. 100 $\mu \mathrm{l}$ of extract or NCTC-109 were added to cultures containing $27 \%$ $\mathrm{PDS}$ and $2 \mathrm{IU} / \mathrm{ml}$ erythropoietin. Mean $\pm \mathrm{SE}$ stimulation in quadruplicate fibrin clot cultures is shown for five separate experiments, relative to NCTC-109 containing cultures. $P<0.01$ for each, as determined by Student's $t$ test.

In addition, washed platelets were alternately frozen and thawed and either incubated at $100^{\circ} \mathrm{C}$ for $10 \mathrm{~min}$ or sonicated. To determine whether stimulatory products were released, supernatants were then added to culture. We found them to contain colony stimulatory activity (see Table I), thereby confirming our observation that platelet-derived products contain growthpromoting activity.

Effects of partially purified PDGF on colony growth. We next tested a partially purified PDGF preparation for erythroid colony stimulatory activity. Fig. 3 demonstrates that this preparation of PDGF at final total protein concentrations of 0.015 to $150 \mathrm{ng} / \mathrm{ml}$ stimulated both CFU-E- and BFU-E-derived colony growth $(P<0.01$ for differences in outcomes at the optimal concentrations of 1.5 and $15 \mathrm{ng} / \mathrm{ml}$ ). PDGF concentrations of $1,500 \mathrm{ng} / \mathrm{ml}$ or greater inhibited colony formation. As anticipated, no growth enhancement was observed when PDS or the high molecular weight platelet glycoprotein thrombospondin was tested (see Fig. 3). Optimal PDGF concentrations also stimulated colony proliferation at erythropoietin doses of $0.1,0.5$, 1 , and $4 \mathrm{IU} / \mathrm{ml}$ (data not shown). No colonies formed in the absence of added erythropoietin.

Not only the number, but also the size of erythroid colonies was increased by PDGF. While two-thirds of CFU-E derived colonies in control cultures with NCTC-109 consisted of between 8 and 20 benzidinepositive cells, two-thirds of colonies in PDGF containing cultures consisted of 25-55 cells. A less marked PDGF effect was observed on BFU-E-derived colony size.

Since it is possible that PDGF may be the critical serum growth factor, we tested varying PDGF concentrations in cultures containing no other serum con- stituent. Fig. 4 shows that no colonies formed in serumfree cultures containing partially purified PDGF. We also assayed colony growth in cultures with varying concentrations of PDS and a constant amount of PDGF. Increasing concentrations of PDS were associated with higher numbers of CFU-E derived colonies (see Fig. 4). Colony growth in cultures with PDS and PDGF was similar to that in WBS-containing cultures $(P>0.10)$ at all serum concentrations. Similar effects were observed for BFU-E proliferation (data not shown).

Colony stimulation by purified PDGF. To confirm that PDGF is a growth-promoting factor, we added various concentrations of electrophoretically pure PDGF to PDS-containing cultures. As shown in Fig. 5 , colony growth increased to nearly 75 or $85 \%$ of maximal growth obtainable at $27 \%$ FCS with protein concentrations $>0.01 \mathrm{ng} / \mathrm{ml}$ or $>0.001 \mathrm{ng} / \mathrm{ml}$ of two different PDGF preparations. In other studies up to $96 \%$ of maximal growth was recovered. The amount of protein added and colony growth were related to a saturable fashion. Cultures containing pure PDGF

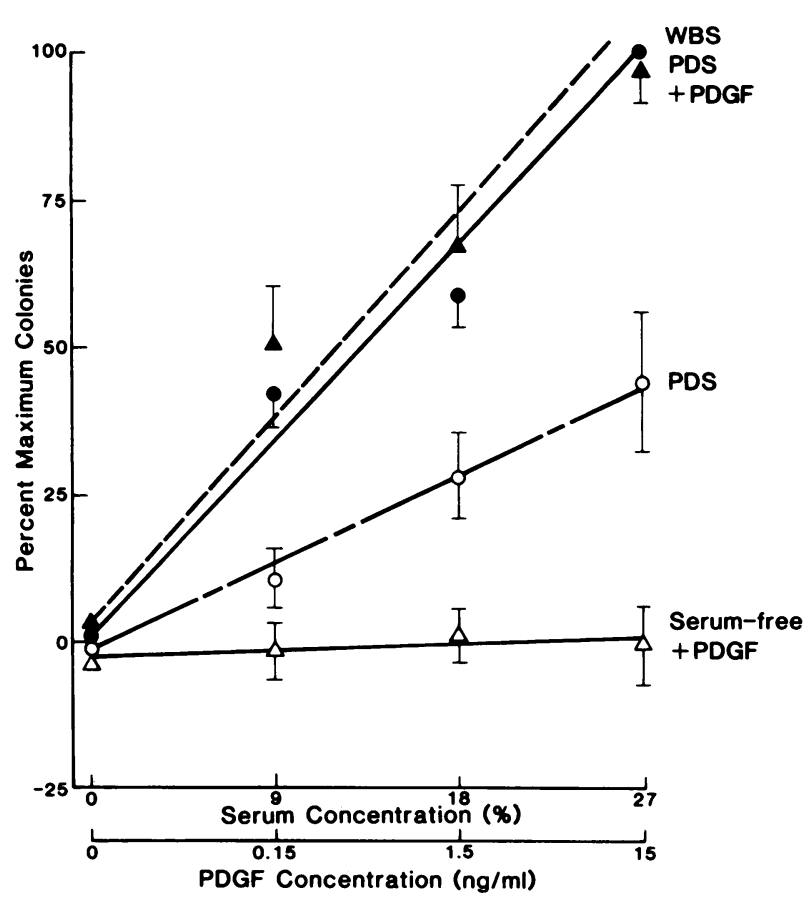

FigURE 4 Support of CFU-E proliferation by WBS, PDS, and/or partially purified PDGF. The graph shows mean $\pm S E$ percent colonies in quadruplicate serum-free cultures containing PDGF $(\Delta)$ and in cultures with WBS $(\bullet)$, PDS alone $(O)$ or PDS plus $15 \mathrm{ng} / \mathrm{ml}$ PDGF $(\Delta)$. All cultures contained $2 \mathrm{IU} / \mathrm{ml}$ erythropoietin. Cultures with $100 \%$ maximum proliferation contained 14 CFU-E-derived and 8 BFU-E-derived colonies $/ 6 \times 10^{5}$ marrow cells. 


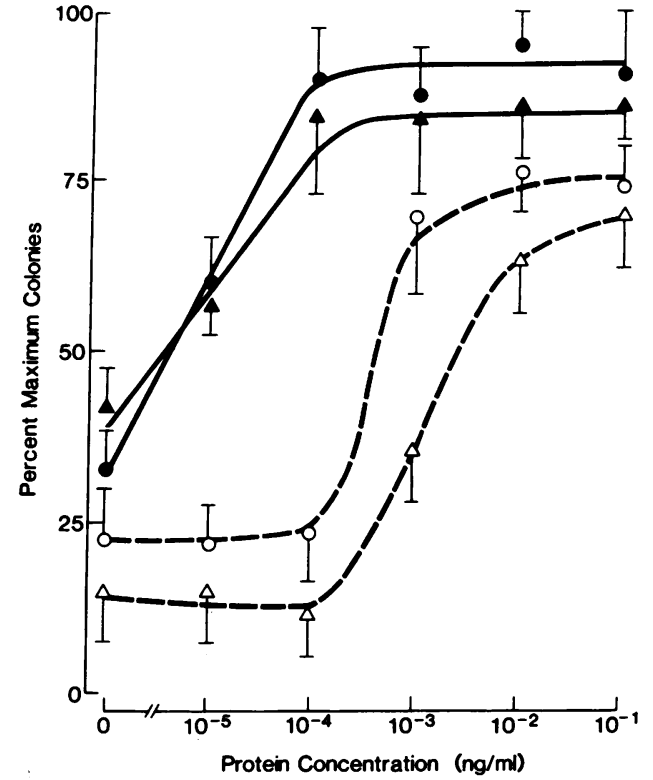

Figure 5 Effects of purified PDGF on colony formation. $100 \mu \mathrm{l}(9 \%, \mathrm{vol} / \mathrm{vol})$ of electrophoretically homogeneous PDGF obtained from Dr. Raines and Dr. Ross (closed symbols) or from Dr. Stiles (open symbols) was added to produce the indicated final protein concentrations. Mean $\pm S E$ percent colonies in quadruplicate cultures is displayed relative to growth in cultures containing $27 \%$ FCS for two separate experiments. Cultures with $100 \%$ maximum proliferation contained either 24 CFU-E-derived and 15 BFU-E-derived colonies $/ 6 \times 10^{5}$ marrow cells (closed symbols), or $18 \mathrm{CFU}$ E-derived and 9 BFU-E-derived colonies $/ 6 \times 10^{5}$ marrow cells (open symbols). All cultures contained $2 \mathrm{IU} / \mathrm{ml}$ erythropoietin. Circles: CFU-E-derived colonies; triangles: BFUE-derived colonies.

at $0.1 \mathrm{ng} / \mathrm{ml}$ protein concentration and $27 \%$ PDS but no added erythropoietin demonstrated no erythroid colony growth. In contrast to these findings in bone marrow cultures, purified PDGF did not alter burst formation in cultures of peripheral blood mononuclear cells (see Table II).

Interaction of PDGF with BPA. To assess the possibility that PDGF activity can replace that of the growth factor erythroid BPA, we measured PDGF effects in marrow and peripheral blood cultures containing various amounts of CM. Fig. 6 shows that when added to marrow cultures containing 4.5\% PDS, 0.01 $\mathrm{ng} / \mathrm{ml}$ of purified PDGF stimulated colony growth at both suboptimal and optimal ( $\geq 9.0 \%) \mathrm{CM}$ concentrations. The level to which PDGF augmented burst formation in serum-restricted cultures was reduced to approximately one-half of that observed in cultures containing $27 \%$ PDS; this reduction was corrected by the addition of CM (see Fig. 6). Table II shows that
TABLE II

Influence of Purified PDGF on Peripheral Blood Burst Formation

\begin{tabular}{|c|c|c|c|}
\hline -Addition to culture & $\%$ & Serum & $\begin{array}{l}\text { \% Maximum burst } \\
(\mathrm{A}, \mathrm{B}, \mathrm{C})\end{array}$ \\
\hline NCTC-109 alone & 27 & FCS & $0,3,0$ \\
\hline Erythropoietin + NCTC-109 & $\begin{array}{c}27 \\
4.5 \\
27\end{array}$ & $\begin{array}{l}\text { FCS } \\
\text { PDS } \\
\text { PDS }\end{array}$ & $\begin{array}{c}100,100,100 \\
12,21,6 \\
83,101,98\end{array}$ \\
\hline PDGF $(0.01 \mathrm{ng} / \mathrm{ml})$ alone & $\begin{array}{c}27 \\
4.5 \\
27\end{array}$ & $\begin{array}{l}\text { FCS } \\
\text { PDS } \\
\text { PDS }\end{array}$ & $\begin{array}{l}0,5,0 \\
0,0,0 \\
0,1,0\end{array}$ \\
\hline $\begin{array}{l}\text { Erythropoietin plus: } \\
\text { PDGF, } 10^{-4} \mathrm{ng} / \mathrm{ml} \\
\text { PDGF, } 10^{-3} \mathrm{ng} / \mathrm{ml} \\
\text { PDGF, } 10^{-2} \mathrm{ng} / \mathrm{ml} \\
\text { PDGF, } 10^{-1} \mathrm{ng} / \mathrm{ml}\end{array}$ & $\begin{array}{l}27 \\
27 \\
27 \\
27\end{array}$ & $\begin{array}{l}\text { PDS } \\
\text { PDS } \\
\text { PDS } \\
\text { PDS }\end{array}$ & $\begin{array}{c}69,97,104 \\
80,101,90 \\
86,87,75 \\
72,93,78\end{array}$ \\
\hline $\begin{array}{l}\text { Erythropoietin plus: } \\
\text { CM, } 4.5 \% \text {, vol/vol } \\
\text { CM, } 9.0 \% \text {, vol/vol } \\
\text { CM, } 18.0 \%, \text { vol/vol }\end{array}$ & $\begin{array}{l}4.5 \\
4.5 \\
4.5\end{array}$ & $\begin{array}{l}\text { PDS } \\
\text { PDS } \\
\text { PDS }\end{array}$ & $\begin{array}{l}15,34,10 \\
76,93,51 \\
91,90,84\end{array}$ \\
\hline $\begin{array}{l}\text { Erythropoietin }+10^{-2} \mathrm{ng} / \mathrm{ml} \\
\text { PDGF plus: } \\
\text { CM, } 4.5 \% \text {, vol/vol } \\
\text { CM, } 9.0 \%, \text { vol/vol } \\
\text { CM, } 18.0 \%, \mathrm{vol} / \mathrm{vol}\end{array}$ & $\begin{array}{l}4.5 \\
4.5 \\
4.5\end{array}$ & $\begin{array}{l}\text { PDS } \\
\text { PDS } \\
\text { PDS }\end{array}$ & $\begin{array}{l}16,19,14 \\
69,85,60 \\
87,92,77\end{array}$ \\
\hline
\end{tabular}

Mean \% maximum growth in quadruplicate fibrin clot cultures is displayed in three separate studies (A, B, C) with purified PDGF obtained from Dr. Raines and Dr. Ross.

- All additions were made at $9 \%(\mathrm{vol} / \mathrm{vol})$, unless otherwise indicated. The erythropoietin dose of $2 \mathrm{IU} / \mathrm{ml}$ was used where indicated.

the addition of various CM concentrations to cultures of circulating erythroid progenitors did not result in a PDGF response.

Assay for erythropoietin activity in WBS, PDS, and partially purified PDGF. WBS, PDS, and partially purified PDGF were tested for erythropoietin activity in the hypertransfused polycythemic mouse and fasted rat systems. Relative to normal saline control samples, these preparations did not increase ${ }^{59} \mathrm{Fe}$ incorporation into erythrocytes (mean incorporations of from 0.00 to 0.02 and from 0.56 to 1.98 for assays in mice and rats, respectively), indicating absence of significant amounts of bioactive erythropoietin in these preparations.

\section{DISCUSSION}

Many hormones and hormone-like substances in mammalian serum influence the proliferation of human 


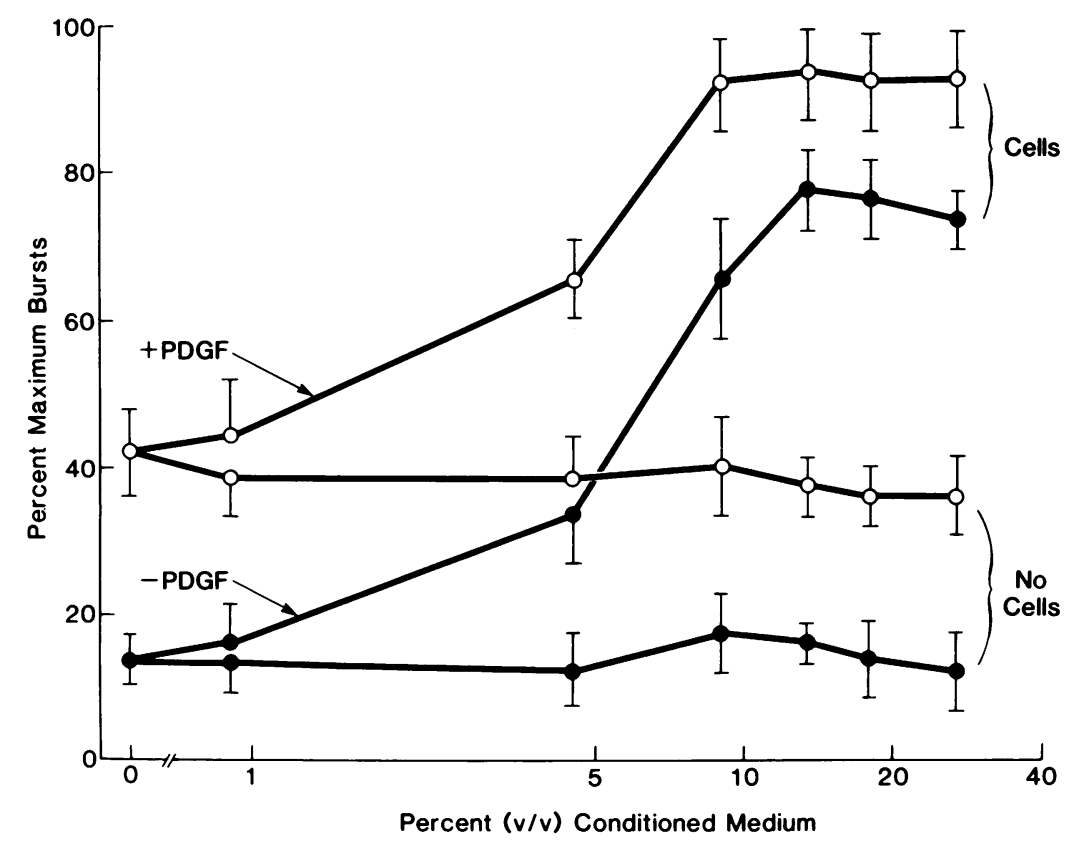

Figure 6 PDGF effects as a function of CM concentration. Mean \pm SE percent maximum growth of quadruplicates at various final $\mathrm{CM}$ concentrations is displayed in cultures containing $2 \mathrm{IU} / \mathrm{ml}$ erythropoietin and either $0.01 \mathrm{ng} / \mathrm{ml}$ of electrophoretically pure PDGF (open circles) or NCTC-109 (closed circles). Test and control media were prepared in the presence of circulating leukocytes (labeled "Cells") or in their absence (labeled "No Cells"), respectively. BPA assays were performed at $4.5 \%$ PDS relative to concurrent cultures containing $27 \%$ FCS without added CM or PDGF. Cultures with $100 \%$ maximum proliferation contained 21 bursts/ $6 \times 10^{5}$ marrow cells.

erythroid progenitor cells $(6,7)$. Several investigators have proposed that serum is a pathological rather than physiological fluid and that, in addition to these growth factors, it may contain numerous mitogenic molecules released from platelets (9-13). In this communication we show that WBS, but not PDS contains a colonypromoting activity for human bone marrow BFU-E and CFU-E. Furthermore, treatment of platelets with thrombin is associated with the release of a factor having mitogenic activity for erythroid progenitors or for other cells that in turn may interact with progenitors in vitro. This activity comigrates with molecules having a molecular weight of $<100,000$. Studies with partially purified and electrophoretically pure PDGF suggest that PDGF most likely accounts for this growth promoting activity.

While the mechanism by which PDGF augments erythropoiesis is not known, several conclusions may be drawn from our observations. First, since erythroid colonies do not appear in erythropoietin-deprived cultures, even if WBS or PDGF is added, the action of PDGF cannot replace that of erythropoietin in bone marrow culture. Moreover, PDGF has no in vivo effect on ${ }^{59} \mathrm{Fe}$ incorporation in the polycythemic mouse assay and, therefore, does not mimic the bioactivity of erythropoietin. Next, the colony stimulatory effect of PDGF is dependent upon the presence of not only erythropoietin but also other factors found in plasma. The latter finding is consistent with the observation that PDGF and plasma constituents may act coordinately in stimulation of cell division of other cell types (12). Finally, because there is a similar growth enhancing effect when PDGF is assayed with optimal or suboptimal BPA concentrations, and since CFU-E derived growth is also stimulated by PDGF, it appears that PDGF activity cannot supplant BPA in vitro. Thus, PDGF is an erythropoietic growth factor that is distinct from apparent erythroid specific growth factors such as erythropoietin and BPA. Its modes of induction of mitogenesis and its interactions with erythropoietin and other private as well as public growth factors present in plasma require definition.

The proliferation of both BFU-E and CFU-E in the bone marrow is increased by PDGF, indicating that the state of differentiation of the marrow stem cell is not a critical factor for this erythropoietic effect. Our 
finding that purified PDGF augments colony growth in a saturable fashion agrees with observations regarding the action of this growth factor (12). In contrast, circulating BFU-E proliferation is unaffected by PDGF. We may speculate that the target cell of PDGF is present in mononuclear cells prepared from bone marrow but is absent from or reduced in those prepared from peripheral blood. Alternatively, it is possible that diminished PDGF binding may explain differences in mitogenic response or that circulating stem cells themselves are qualitatively different from marrow stem cells with respect to PDGF action.

In conclusion, our data suggest that platelets may play a role in the regulation of normal in vitro erythropoietic differentiation by their release of PDGF. Other platelet-derived factors with mitogenic activity for connective tissue cells in culture may also have erythropoietic activity $(17,22,23)$. While various serum growth factors, including erythropoietin and BPA, may be essential for in vitro erythropoiesis, optimal proliferation requires the presence of plateletderived molecules. It is not known whether a similar requirement exists for optimal erythropoiesis in vivo. However, it is now recognized that cellular interactions are important in the regulation of erythropoiesis and that fibroblasts and smooth muscle cells are physically associated with multiple levels of erythroid differentiation within the local environment of mammalian bone marrow (24-26). Since PDGF augments DNA synthesis and division of mesenchymal cells (27, 28) that may in turn stimulate erythropoiesis (29), it is possible that the erythropoietic activity of PDGF may be due to replacement of growth factors for nonerythroid cells that are normally present in bone marrow in vivo. On the other hand, PDGF may replace factors that are mitogenic either for hematopoietic cells in general or for specific erythroid progenitor cell populations. Studies using purified PDGF to obtain hematopoietic populations that are enriched in progenitor cells may elucidate the characteristics of target cells that are required for an erythropoietic effect.

\section{ACKNOWLEDGMENTS}

We are grateful to Dr. Elaine W. Raines and Dr. Russell Ross and to Dr. Charles D. Stiles for their generous supply of purified PDGF. This work was supported in part by $\mathrm{Na}$ tional Institutes of Health (NIH) grants R01 AM27071 and R01 AM31060 to Dr. Dainiak, by NIH Clinical Investigator award HL00902 to Dr. Davies and by NIH New Investigator Research award 1R23 HL28749 to Dr. Lawler.

\section{REFERENCES}

1. Metcalf, D. 1977. Hemopoietic colonies: in vitro cloning of normal and leukemic cells. Springer-Verlag, New York. 160-170.
2. Ham, R. G., and W. L. McKeehan. 1979. Media and growth requirements. In Methods in Enzymology. Cell Culture. W. B. Jakoby and I. H. Pastan, editors. Academic Press, Inc., New York. Vol. LVIII. pp. 44-03.

3. Barnes, D., and G. Sato. 1980. Methods for growth of cultured cells in serum-free medium. Anal. Biochem. 102: 255-270.

4. Guilbert, L. J., and N. N. Iscove. 1976. Partial replacement of serum by selenite, transferrin, albumin and lecithin in haemopoietic cell cultures. Nature (Lond.). 263: 594-295.

5. Iscove, N. N., L. J. Guilbert, and C. Weyman. 1980. Complete replacement of serum in primary cultures of erythropoietin-dependent red cell precursors (CFU-E) by albumin, transferrin, iron, unsaturated fatty acid, lecithin and cholesterol. Exp. Cell. Res. 126: 121-126.

6. Adamson, J. W. 1981. Hormonal interactions in erythropoiesis. In Hemoglobins in Development and Differentiation. G. Stamatoyannopoulos and A. W. Neinhuis, editors. Alan R. Liss, Inc., New York. pp. 73-84.

7. Golde, D. W. 1978. Hormonal modulation of erythropoiesis in vitro. In In Vitro Aspect of Erythropoiesis. M. J. Murphy, editor. Springer-Verlag, New York. pp. 81-85.

8. Bottenstein, J., I. Hayashi, S. Hutchings, H. Masui, J. Mather, D. B. McClure, S. Ohasa, A. Rizzino, G. Sato, G. Serrero, R. Wolfe, and R. Wu. 1979. The growth of cells in serum-free, hormone-supplemented media. In Methods in Enzymology: Cell Culture. W. B. Jakoby and I. H. Pastan, editors. Academic Press, Inc., New York. Vol. LVIII. pp. 94-109.

9. Ross, R., J. Glomset, B. Kariya, and L. Harker. 1974. A platelet-dependent serum factor that stimulates the proliferation of arterial smooth muscle cells in vitro. Proc. Natl. Acad. Sci. USA. 71: 1207-1210.

10. Antoniades, H. N., D. Stathakos, and C. D. Scher. 1975. Isolation of a cationic polypeptide from human serum that stimulates proliferation of 3 T 3 cells. Proc. Natl Acad. Sci. USA. 72: 2635-2639.

11. Ross, R. 1981. The platelet-derived growth factor: a perspective. In Control of Cellular Division and Development, Part A. D. Cunningham, E. Goldwasser, J. Watson, and C. F. Fox, editors. Alan R. Liss, Inc., New York. pp. 503-506.

12. Vogel, A., E. Raines, B. Kariya, M. Rivest, and R. Ross. 1978. Coordinate control of $3 \mathrm{~T} 3$ cell proliferation by platelet-derived growth factor and plasma components. Proc. Natl. Acad. Sci. USA. 75: 2810-2814.

13. Vogel, A., R. Ross, and E. Raines. 1980. Role of serum components in density-dependent inhibition of growth of cells in culture. Platelet-derived growth factor is the major serum determinant of saturation density. $J$. Cell Biol. 85: 377-385.

14. Lowry, O. H., N. J. Rosebrough, A. L. Farr, and R. J. Randall. 1951. Protein measurement with the Folin phenol reagent. J. Biol. Chem. 193: 265-275.

15. Lawler, J. W., H. S. Slayter, and J. E. Coligan. 1978. Isolation and characterization of a high molecular weight glycoprotein from human blood platelets. J. Biol. Chem. 253(23): 8609-8616.

16. Tepperman, A. D., J. E. Curtis, and E. A. McCulloch. 1974. Erythropoietic colonies in cultures of human marrow. Blood. 44: 659-669.

17. Raines, E., and R. Ross. 1982. Platelet-derived growth factor. I. High yield purification and evidence for multiple forms. J. Biol. Chem. 257: 5154-5160. 
18. Antoniades, H. N., C. D. Scher, and C. D. Stiles. 1979. Purification of human platelet-derived growth factor. Proc. Natl. Acad. Sci. USA. 76: 1809-1813.

19. Dainiak, N., and C. M. Cohen, 1982. Surface membrane vesicles from mononuclear cells stimulate erythroid stem cells to proliferate in culture. Blood. 60: 583-594.

20. Goldstein, A. 1964. Biostatistics, an Introductory Text. The Macmillan Company, New York. p. 62.

21. Shadduck, R., D. Howard, and F. Stohlman, Jr. 1968. A difference in erythropoietin production between anemic and hypoxic mice. Proc. Soc. Exp. Biol. Med. 128: 132-136.

22. Kepner, N., G. Creasy, and A. Lipton. 1978. Platelets as a source of cell-proliferating activity. In Platelets: A Multidisciplinary Approach. Raven Press, New York.

23. Zetter, B. R., and H. N. Antoniades. 1979. Stimulation of human vascular endothelial cell growth by a platelet derived growth factor and thrombin. J. Supramol. Struct. 11: 361-370.
24. Cline, M. J., and D. W. Golde. 1979. Cellular interactions in hematopoiesis. Nature (Lond.). 277: 177-181.

25. Zanjani, E. D., and M. E. Kaplan. 1979. Cell-cell interaction in erythropoiesis. Prog. Hematol. XI: 173-191.

26. Weiss, L. 1981. Haemopoiesis in mammalian bone marrow. In Microenvironments in Haemopoietic and Lymphoid Differentiation. Ciba Found. Symp. 84: 5-48.

27. Rutherford, R. B., and R. Ross. 1976. Platelet factors stimulate fibroblasts and smooth muscle cells quiescent in plasma serum to proliferate. J. Cell Biol. 69: 196-203.

28. Ross, R., C. Nist, B. Kariya, M. J. Rivest, E. Raines, and J. Callis. 1978. Physiological quiescence in plasma derived serum: influence of platelet derived growth factor on cell growth in culture. J. Cell. Physiol. 97: 497-508.

29. Ghio, R., G. Bianchi, B. Lowenberg, K. A. Dicke, and F. Ajmar. 1977. Effects of fibroblasts on the growth of erythroid progenitor cells in vitro. Exp. Hematol. 5: 341347. 